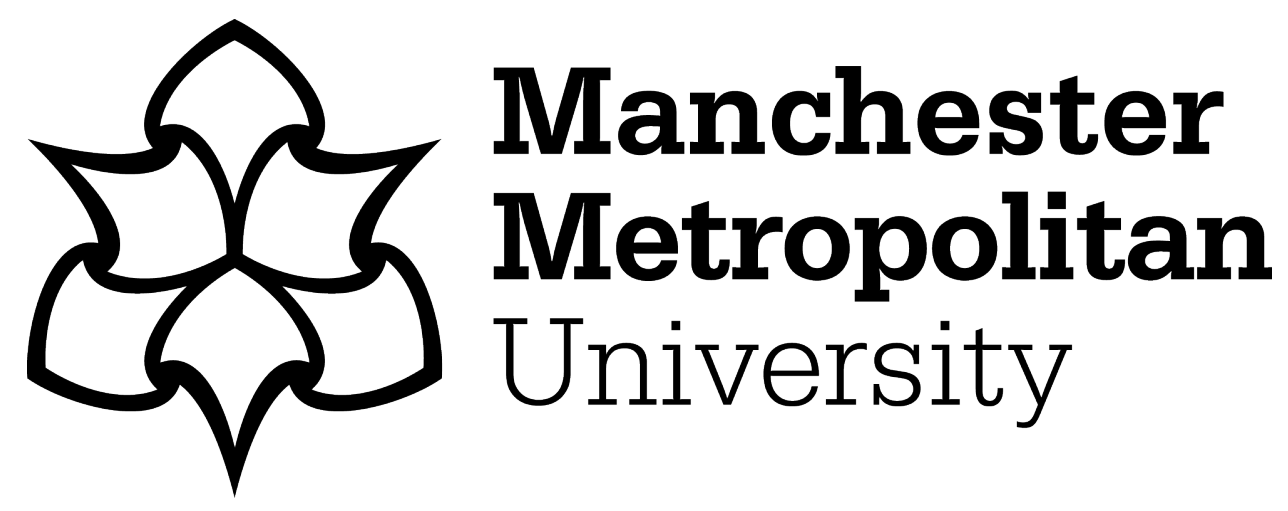

Rousell, David and Fell, F (2018) Becoming a Work of Art: Collaboration, Materiality and Posthumanism in Visual Arts Education. International Journal of Education through Art, 14 (1). pp. 91-110. ISSN 1743-5234

Downloaded from: https://e-space.mmu.ac.uk/619021/

Version: Accepted Version

Publisher: Intellect

DOI: https://doi.org/10.1386/eta.14.1.91_1

Please cite the published version 


\title{
Becoming a Work of Art: Collaboration, Materiality and Posthumanism in Visual Arts Education
}

\author{
David Rousell (Manchester Metropolitan University) \\ Fiona Fell (Southern Cross University)
}

\begin{abstract}
Collaboration has become a core aspect of teaching, learning and research in university art departments, especially as contemporary artists have increasingly turned to collective and sociallyengaged studio practices. Despite this, hylomorphic approaches to arts education continue to position matter as a passive substance to be shaped by the artist(s) in service of linguistic discourse. In this paper, we ask how a new materialist approach to collaboration might disrupt humanist ontologies of visual arts education in the university. We firstly draw on posthumanist writings to recompose collaboration in ways that are responsive to the specificity of material entanglements as they are enacted within an ecology of studio practices. From there we work diagrammatically across a collaborative 'data event' of art in the making, drawing on a year-long participatory study with a cohort of third year art students. In the final section, we develop propositions for collaboration as a transversal practice of 'becoming a work of art'.
\end{abstract}

Keywords: collaboration; curriculum studies; visual arts education; higher education; posthumanism; new materialism

\section{Introduction}

Collaboration has become a central mode of creative production in the visual arts since the mid- $20^{\text {th }}$ century, as influenced by relational practices associated with environmental, performative, ethnographic, community-based, activist and socially-engaged art (Foster 1996; Sholette 1999). Visual arts programs in colleges and universities have in turn shifted to encompass collective, interdisciplinary and community-based collaborations as core components for undergraduate degrees in recent years (Buckley and Conomos 2009; Salazar 2013). This collaborative turn in postsecondary arts education, however, presents a profound disruption of humanist ontologies that have foregrounded the personal expression, skill and conceptual strength of the individual human subject (Ewing 2009; Rousell and Cutcher 2014). This ontological privileging of human cognition in the creative process has been further perpetuated through the legacy of cultural relativism and postmodernism in the 1980 s and 1990 s, a movement that framed university arts education primarily in terms of linguistic discourse and ideological representation. Bolt (2013:4) describes this as a 'colonisation of the arts by cultural theory', such that the identity of the artist and the work of art are ultimately constructed in and through language. Becoming an artist in the university has too often been reduced to the development of a visual 'language' to be imposed on matter, and thus commodified as an epistemological object of visual culture under the neoliberal regime of 'designer capitalism' (jagodzinski 2015).

This article responds to resonant calls within the field for the development of flexible, collaborative, conceptually-driven, multidimensional and multisensorial pedagogies in visual arts education that are both attuned and responsive to the rapidly changing social, technological and environmental conditions of life in the Anthropocene epoch (Conomos 2009; Ewing 2009; Garoian 2014; jagodzinski 2015). In developing such alternative propositions for arts education in the university, we draw on posthumanist scholarship that has foregrounded the vibrant and distributed materiality of creative practice outside the limitations of anthropocentric and humanist thought (Bolt 2013; Rotas and 
Springgay 2015). More specifically, we explore how collaboration might begin to operate in visual arts programs through a new materialist philosophy of becoming (Coole and Froste 2010; Dolphijn and van der Tuin 2012). In doing so, we seek to contribute to the relatively small body of empirical scholarship on studio pedagogies and curriculum theory in post-secondary visual arts education, an area that has received limited attention in the broader field of arts education research (Salazar 2013).

\section{Beyond Hylomorphism and Representation}

Theoretical movements associated with new materialist scholarship have recently challenged the hylomorphic and representational ontologies underpinning humanist modes of visual arts education (Bolt 2013; Rotas and Springgay 2015). Historically, hylomorphic models of arts education have positioned matter as an inert, passive substance to be formed by the trained hand of the maker, in service of 'higher' cognitive and linguistic concepts (Ingold 2013: 21). Such ontologies delimit artistic practice as an operation 'that moulds matter into forms according to an ideal model, an operation by which the world appears as obedient and predictable representations' (Zepke 2005: 3). The hylomorphic valuation of 'mind over matter' has been further emphasised by poststructuralist and social constructivist approaches to arts education, which often position the work of art as a 'cultural object of knowledge', albeit one that offers multiple discursive interpretations and meanings (jagodzinski and Wallin 2013: 192). Under such regimes, artworks are commonly accorded status as representations of an artist's personal experience and intentionality imposed upon matter, representations that are subsequently evaluated by the viewer, audience or spectator as cultural knowledge. In this sense, the elevation and stratification of arts education as a rarefied form of knowledge production ensures that the vicious circles of hylomorphism and discursive representation are upheld. This has the effect of inhibiting the unique potential for art to explore creative modes of thinking and practice that resist the capture of human language and cognition (Rousell 2017).

Posthumanist reconceptualisations of arts education have also been called for in response to the Anthropocene epoch, a time in which 'representation is no longer adequate to the task of inventing new potentials and styles of living' (jagodzinski and Wallin 2013: 188). In times of accelerating social and ecological instability, the geo-philosophy of Deleuze and Guattari (1987) offers an alternative vision of arts education as a process of working collaboratively with the potentials and variations of living matter through experimental modes of practice. In breaking with the hylomorphic tradition, arts education can begin to inhabit processes that follow the flows of affect and materiality in relation to elemental forces, tensions, patterns, movements and bodily sensations (Deleuze and Guattari 1987). This is the process of following the grain of a piece of wood, stone or metal as a sculpture takes form, or of following the chemical variations of colour and viscosity as different paints come into contact. Ingold (2013: 25) describes such processes as learning to work with 'the grain of the world's becoming', and thus learning to modulate potentials for material variation and difference as they emerge through practice. In this way, arts education is reconceptualised as learning to 'live a life proper to matter as such, a material vitalism that doubtless exists everywhere but is ordinarily hidden or covered, rendered unrecognisable, dissociated by the hylomorphic model' (Deleuze and Guattari 1987: 411).

In responding to these new materialist conceptualisations of matter and agency, this article develops a vision of arts education as a collective process of becoming a work of art, rather than an individual process of becoming an artist. This means that a work of art is no longer considered the material and 
intellectual product of an individual human subject, but rather, a dynamic assemblage of multiple agencies and processes that disrupt and interfere with one another within an 'ontologically heterogeneous field' of relations (Bennett 2010: 23). To collaborate, then, is to become entangled with 'the shared materiality of all things[...] of which we are all composed' (12-13). Every artwork is, in this sense, always already collaborative inasmuch as it exists materially and makes a difference in reality in some way. In other words, we argue that art is a 'co-collaboration' in which 'matter as much as the human has responsibility for the emergence of art' (Bolt 2013: 6). This is to re-orientate the aims of arts education towards 'inventing new possibilities of life', and thus opening up new potentials for 'existing not as a subject but as a work of art' (Deleuze 1995: 95).

In the following sections, we explore what it might mean to become a work of art collaboratively, and the implications of this thinking for a posthumanist curriculum in the visual arts. In doing so, we draw on participatory research undertaken with a group of twenty visual arts students in a regional university as part of a larger creative research project called States and Territories, which reimagines a university campus through relational artworks, curricular experimentations and locationbased media. Each of the participating visual art students undertook their own collaborative projects within the context of a 'data event', collectively documenting their thoughts and processes for inclusion in one of twelve digital archives located across the university (Rousell 2017). After briefly outlining States and Territories as the methodological context for this creative research, we work through a diagrammatic account of the data event as a relational process that moves across bodies, materials, surfaces and articulations. This involves not only a performative working through of the research data as event, but also a series of tentative curricular movements towards collaboration as a diffractive practice that produces new ecologies of participation. Through this diagrammatic process, we set in motion a series of propositions for reworking the visual arts curriculum in ways that challenge the anthropocentric underpinnings of normative arts education practice. Rather than imposed curricular limitations, these are proposed as ruptures or openings to foster material becomings of the types posed by Deleuze and Guattari (1987): becoming-child, becoming-animal, becoming-woman and becoming-molecular.

\section{States and Territories: A Collaboration in the Making}

The concepts and practices that we develop in this article are contextualised within a larger project called States and Territories, which co-author David undertook as his doctoral project between 2013 and 2016. States and Territories aimed to re-imagine university learning environments in response to the onset of the Anthropocene, a time typified by anthropogenic climate change, catastrophic loss of biodiversity, social and political upheaval, ubiquitous computation along with rampant advances in the biosciences and biotechnologies (Rousell 2016). Central to the States and Territories project has been the permanent installation of interactive artworks and multimedia interfaces across the learning environments of Southern Cross University's campus in Lismore, NSW Australia. Each installation has taken the form of a glass cube that maps the surrounding learning environment using photographic images captured from the object's own point of view within the landscape. These twelve installations have operated as pedagogical pivot points for engaging with data events that have been collectively produced with students and academics working in the visual arts, media studies, cultural studies, education, law and justice, engineering, ecology, chemistry and environmental science. Each of the twelve data events has explored a different concept through curricular experimentations with speculative ideas, materials and media, including the concepts of becoming, affect, engagement, movement, ecology, mapping, materiality, collaboration and imagining (see Figure 1). 


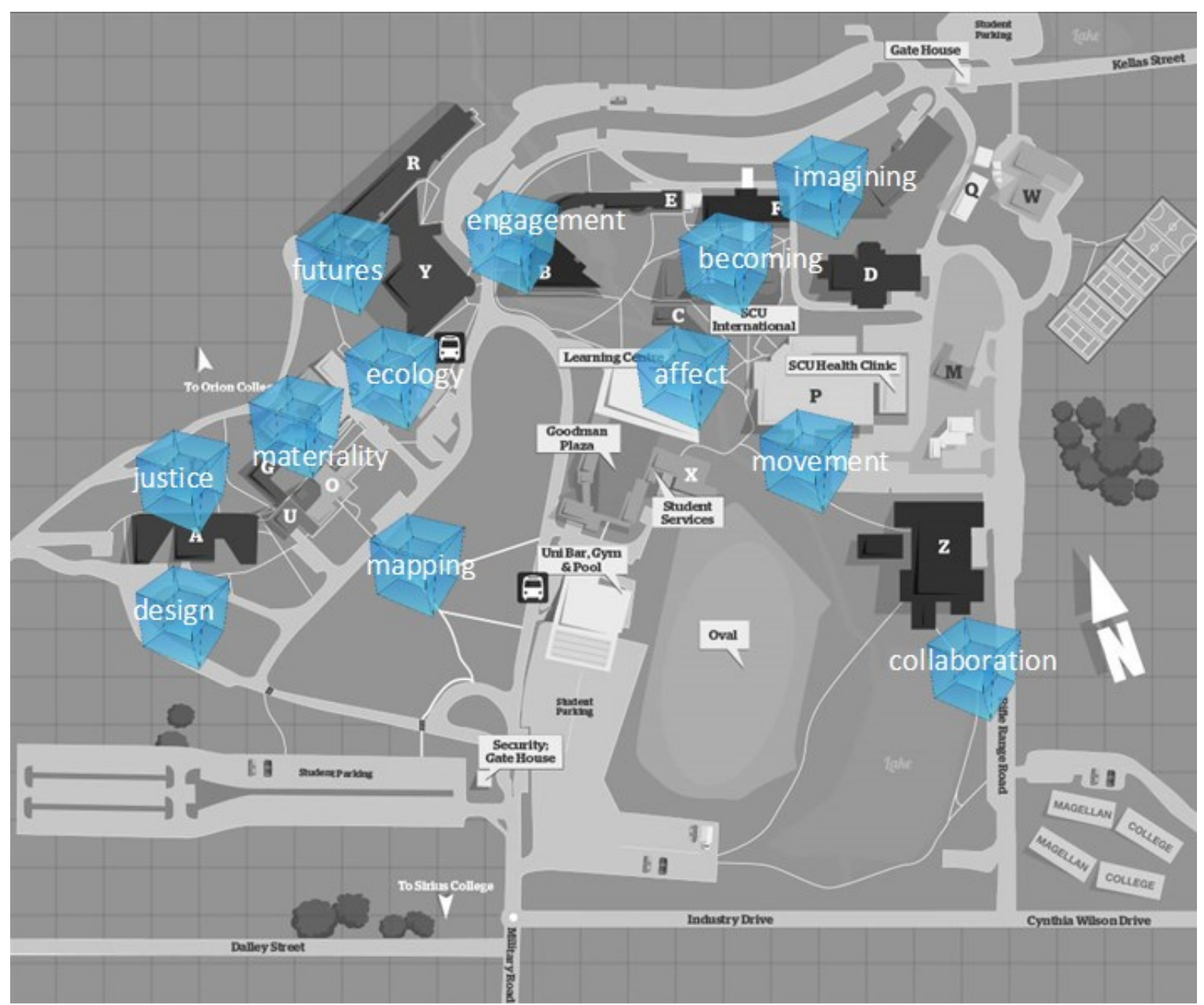

Figure 1: Map showing the distribution of artworks as conceptual territories across the learning environments of SCU's Lismore campus.

In this article, we focus on the data event associated with the concept of collaboration, which involved working with a group of twenty visual arts students over a period of six months. The data event began with the installation of the 'collaborations cube' on the banks of a small lake on the Lismore campus of Southern Cross University. As shown in Figure 2, the cube's five faces generate a series of diffraction patterns in relation to the learning environment that surrounds the installation, such that the surfaces of the cube continuously produce new compositions of light, colour, movement, sensation and feeling. Using the collaboration cube as the pivot point for a series of pedagogical and curricular experimentations, David began working closely with Fiona (co-author and lecturer in Visual Arts Studio Studies) to integrate the States and Territories project with the student collaboration project in the Bachelor of Visual Arts program. Historically, the collaboration project has performed a disruptive function in pushing the students' artmaking practices beyond habitual and predetermined processes in the development of their final bodies of work. In this case, we 
aimed to push these collaborations even further by introducing elements of new materialist theory and arts-based research methods into the mix.

The visual arts students' first encounter with States and Territories was through David's delivery of a central lecture entitled Collaboration After Humanism. Key elements of the lecture included working in collective networks and assemblages (Bennett 2010); moving beyond humanist notions of individual agency and author(ity) (Braidotti 2013); and becoming "not ourselves" through more than human collaborations (Cutcher, Rousell and Cutter-Mackenzie 2015). David also created an online interface that gave students access to a recording of the lecture, links to relevant websites and readings, a discussion forum along with a portal for submitting text, photos, audio and video into the cube's archive on collaboration: www.statesandterritories.org/collaboration.
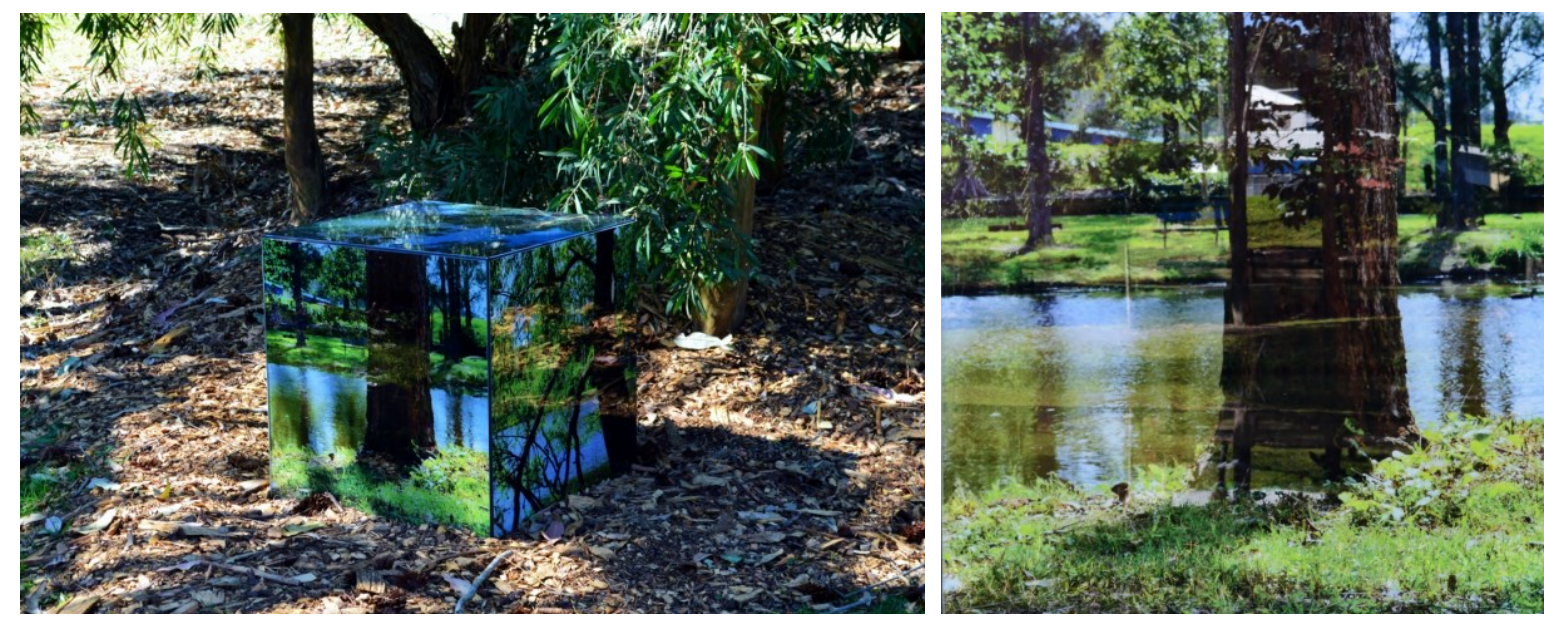

Figure 2: The Collaboration cube located near the campus lake, medicinal garden and koala sanctuary (left); detail of the cube face showing the diffraction between surfaces of light, colour and movement.

Following the guest lecture, students began developing their own processes of collaboration while also using iPads to record their material studio practices and conceptual thinking at various points during the semester. The students also took on the curatorial process of producing an exhibition of their collaborative artworks, which forced them to negotiate each other's practices in relation to the formal constraints of space, and enabled them to enter into an expanded political ecology associated with a public encounter. As it unfolded over the course of the semester, the data event yielded a large amount of video, audio, photographic and textual data as collectively generated by the students and ourselves as researchers, as aided by a host of other human and nonhuman collaborators. These materials then served as the basis for a multi-sensory cartography that maps various elements of the collaboration data event, and which can be accessed in the archive hosted on the States and Territories website: www.statesandterritories.org/collaboration-archive.

\section{The Data Event}

As described above, the collaboration project enabled us to think and work together with students in actively constructing the concept and practice of collaboration through a new materialist lens, while simultaneously experimenting with alternative pedagogies and curricular framings for visual arts education. Central to this process was the methodological concept of the data event, which is attuned to the performativity of a research event that does not cleave the datum from the situated material entanglements through which it is produced (Rousell 2017). Because immersive 
cartography does not separate the datum from the experiential event of encounter, there is no position from outside the data event from which it can also be experienced. This means that every encounter with data produces something new, and we are therefore interested in what the data can do when plugged into various creative and theoretical processes. While the collaboration cube and its associated interfaces offer a pedagogical pivot point for encounters with research data, the data event is not reducible to any simple location or object. Rather, what we are calling the data event is a multiplicity of disjunctive spaces and temporalities that cut into one another to produce difference with each encounter:

The cube cuts into the learning environment to open up new ecologies of experience on the campus/States and Territories cuts into the student collaboration project to disrupt the humanist underpinnings of the visual arts/the art students cut material practices into States and Territories as they document their studio processes/the collaborations cut into the students' bodies as their practices are altered by relational encounters with multiple others/this paper cuts into the data event to reconfigure the curriculum for future students/the reader cuts into the paper to think and practice their own account of its unfolding.

As Barad (2007: 175) describes, each of these cuts is agential in altering the causal structure of possibility conditions for the data event to occur. Different cuts produce different phenomena inside the data event as a multiplicity that oscillates between indiscernibility (potentiality) and objectification (concrescence). Each cut is a new occasion for an affective encounter that feels the data of the actual world differently (Whitehead 1978). Put simply, every encounter with the data produces something new.

In the following sections, we use diagramming as a post-qualitative analytic technique that cuts across the contours and surfaces of the collaboration data event to produce new potentials for visual arts pedagogy and curriculum (Lather and St. Pierre 2013). Pieces of images, sounds, texts, thoughts, sensations and movements are brought into consequential relation in the cutting together of becomings of the types activated by Deleuze and Guattari (1987): becoming-child, becominganimal, becoming-woman and becoming-molecular. Each diagram maps the operations of the data event across different strata, surfaces, territories and domains. In this way, each diagram experiments materially with what the data can do, rather than attempting to interpret what the data 'means' as a reflection or representation of phenomenological, ethnographic or even artistic experience (MacLure 2013). The heterogeneous voices of students, teachers, researchers, theorists, materials and artefacts are thus de- and re-composed in an attempt to foreground material processes of becoming that occur outside of 'subject-predicate' discourse. Significantly, the diagram also plays a piloting role in opening up new lines of 'creation and potentiality' that have implications for pedagogical practice and curriculum (Deleuze and Guattari 1987: 142). Hence, the four diagrams below work speculatively and propositionally to develop the conceptual assemblage of 'becoming a work of art', while also mobilising the problem of how this new assemblage might produce curriculum otherwise.

\section{Becoming-Child}

We [create] not with childhood memories but through blocs of childhood that are the becoming-child of the present. (Deleuze and Guattari 1994: 168) 
How do you translate that jellyfish onto the canvas? And the kids just see it as the head and the squiggly lines.

So, as adults we tend to think about the image of what it will look like and say.

The thinking about what happens when I make that mark. But with the kids they don't think about what happens when I put a jellyfish there. They just put it there. It just happens. There's no preconceptions about all of that.

Yeah, it's that guy, that jellyfish.

He's that jellyfish.
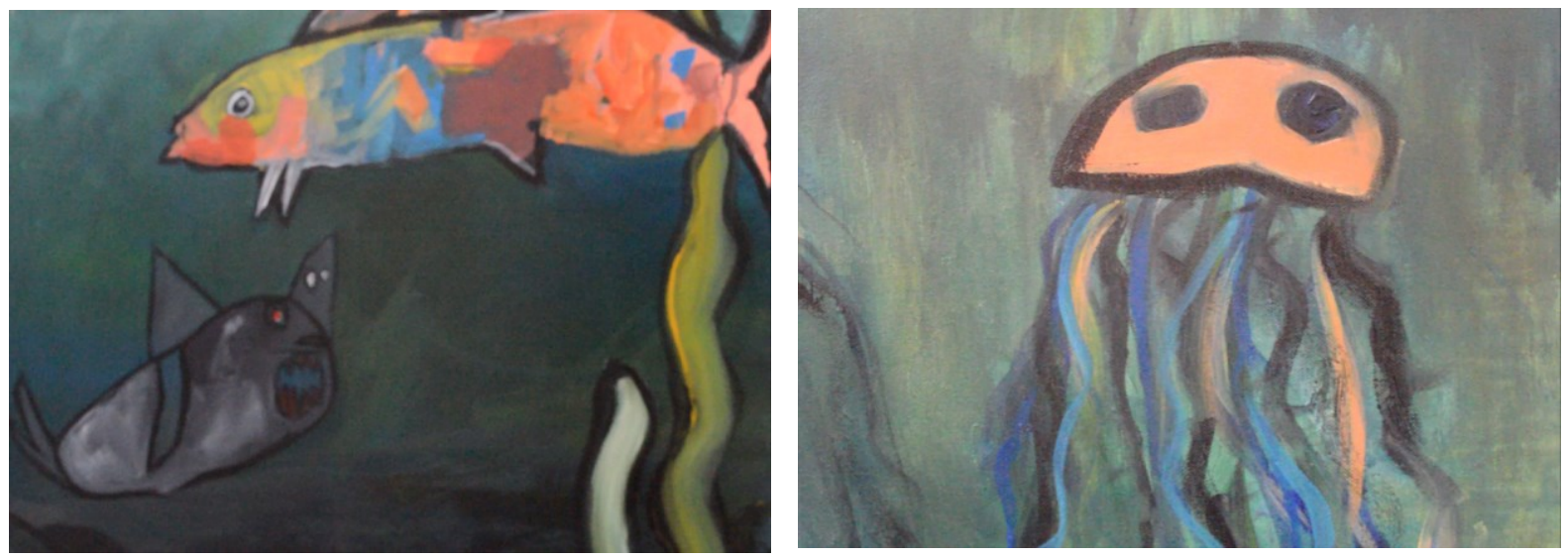

Figure 3: Emily Imerson, Loan Fish Fish Dinner (detail), 2015, acrylic on canvas. Used with permission. Photos by David Rousell.

We did talk about 'where should the fish go?' And 'where is the shark going to go?' And the fish went on first and it was a big fish. And then we thought, 'the shark's going to be smaller than the fish.' And then we realised that doesn't matter, because it could be far away in the distance in the ocean. And then we had the angle of the small predator going for the large prey.

This one I had the background prepared, so I had a red background with two yellow lines running through the middle. And my six year old niece just picked up a paint brush and slapped on some blue and said, 'yellow goes there and green down the bottom'. She didn't seem to think about it too much. She just did it.

So how do you account for children's ability to do that, to compose an image almost without realising it?

This was my nephew, he's eleven. But he loves the ocean so he knew exactly what he was going to paint, straight away he was going to paint the picture in his mind of the beach. And he just went for it. The way he moved the paint around the canvas was so beautiful, it was in harmony. Bit more yellow, bit more yellow, bit more... yellow, then go into the blue.

And he had this wonderful free movement over the canvas. And he wasn't afraid of the drips, he didn't try to contain the paint.

It's the way that children will paint or draw not what it looks like, but what it feels like. So, the suggestion of a different perspective, or a different approach. 


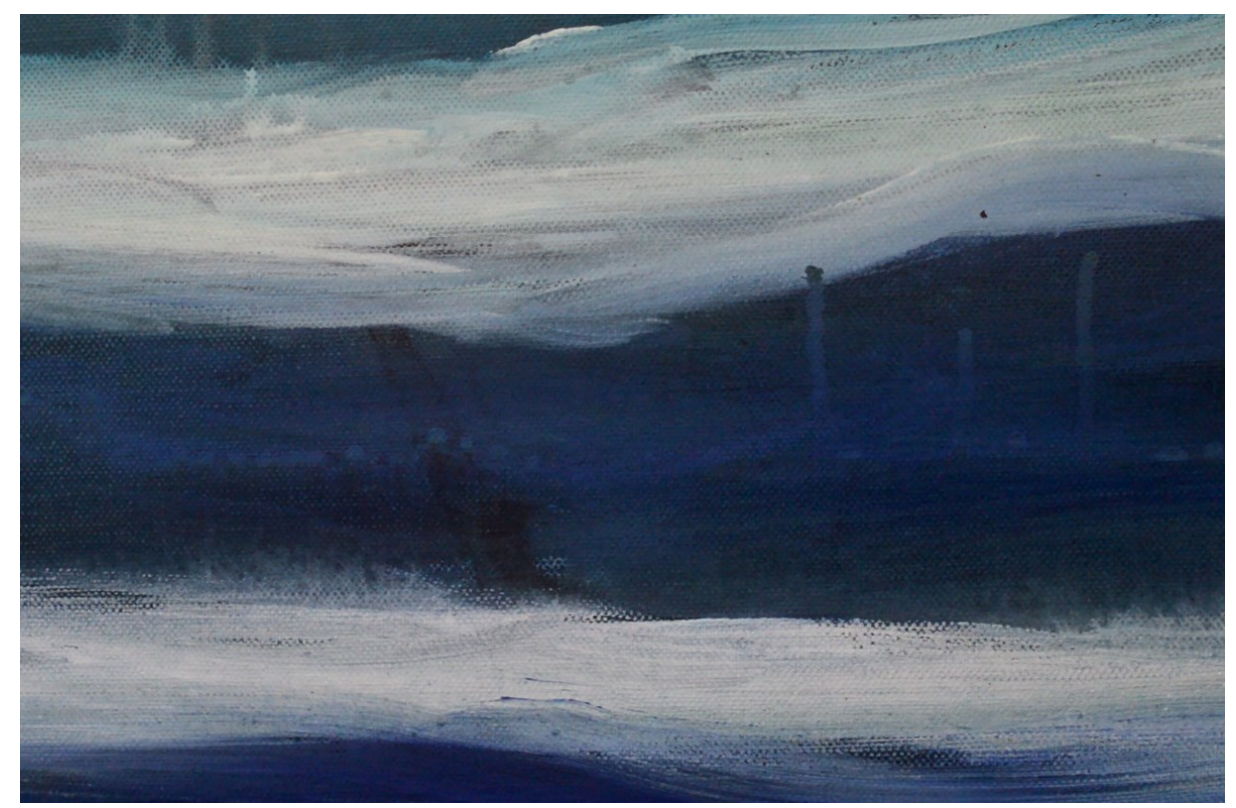

Figure 4: Emily Imerson, Loan Fish Fish Dinner (detail), 2015. Acrylic on canvas. Used with permission. Photo by David Rousell.

A different approach, but their perspective was so influential on me. The naive marks and the starfish that's not even on any side. That's just how it comes out through the paintbrush.

There's this underlying sense that everything we do in art needs to be conceptually backed up or rationalised or referring to something outside of itself...

...especially in university.

How can we disrupt what we think art is? Our habitual thought patterns around what 'does an artist do?', and 'how we can teach and learn art in purposeful ways?' We can locate these ideas in the history of art as well, we don't have to go back too far to find someone like Cezanne who looked at painting as pure sensation rather than a conceptual or cognitive practice.

Doing art with kids who aren't involved directly with art, so bringing them into the paintbrush and the paint, re-telling the story of the art practice to children. And that brought forward these processes that l'd forgotten or pushed down...

\section{Becoming-Animal}

[...]do not look for a resemblance or analogy to the animal, for this is becoming-animal in action, the production of the molecular animal[...] it is within us that the animal bares its teeth[...] the flower opens its petals; but this is done by corpuscular emission, by molecular proximity, and not by the imitation of a subject or a proportionality of form. (Deleuze and Guattari 1987: 275) 
For some reason our interests are drawn towards certain objects, animals, places, tastes, sounds, smells and colours/Bringing together differing and yet similar minds in collaboration/things paired by default, humour, contrast/ positioned to be blurred, obvious, interesting, harmonious and questionable...

Asymbiotic and cruel relationalities/mutant subjectivities/night cries of co-predation/the rewilding of the animal body/a cup of tea and a carnivore/three thousand types of species/each emitting particle-signs...

A feathery tuft and a pair of tentacles in front/they are both sexes but need a male to reproduce/eat corals, sponges, anemones, sea pens/gentle and graceful carnivores/colour combinations are endless/have no known predators...
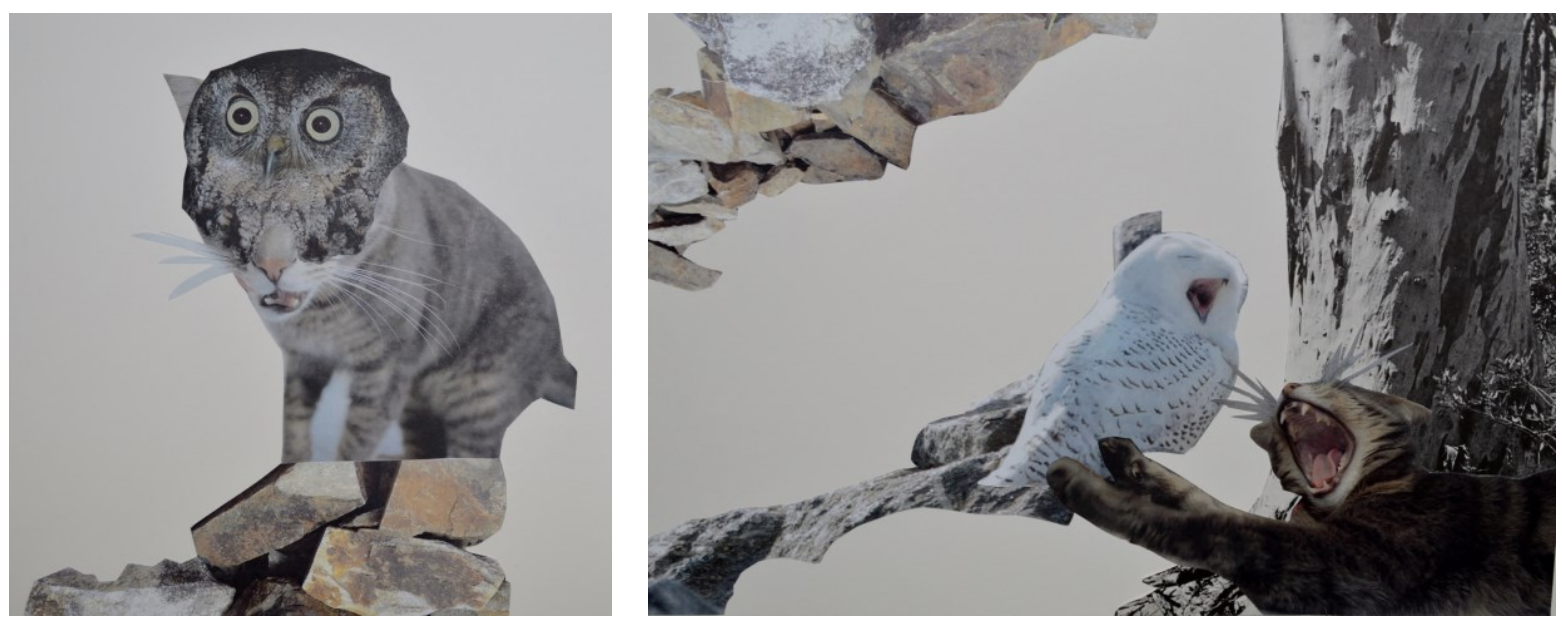

Figure 5: Jessica Mattner, Our Favourite Things (details), 2015, collage on paper. Used with permission. Photos by David Rousell.

Animal elegance, the camouflage fish, the clandestine: this fish is crisscrossed by abstract lines that resemble nothing, that do not even follow organic divisions; but thus disorganised, disarticulated, it worlds with the lines of rock, sand and plants, becoming imperceptible (Deleuze and Guattari 1987: 280)

Tea being 3000 types from the same basic plant/differentiation arises from processing, growing conditions and geography/global consumption only surpassed by water and enjoyed in company... To compose a molecular body with the animal/vegetable/mineral that we are, that we eat, that we create, that we become...

I just went with the process, with what my grandmother was doing... she's not an artist but I think of her as an artist because she just sees so much in everything... so we were bringing together both of our worlds, and placing them on the same page together... 

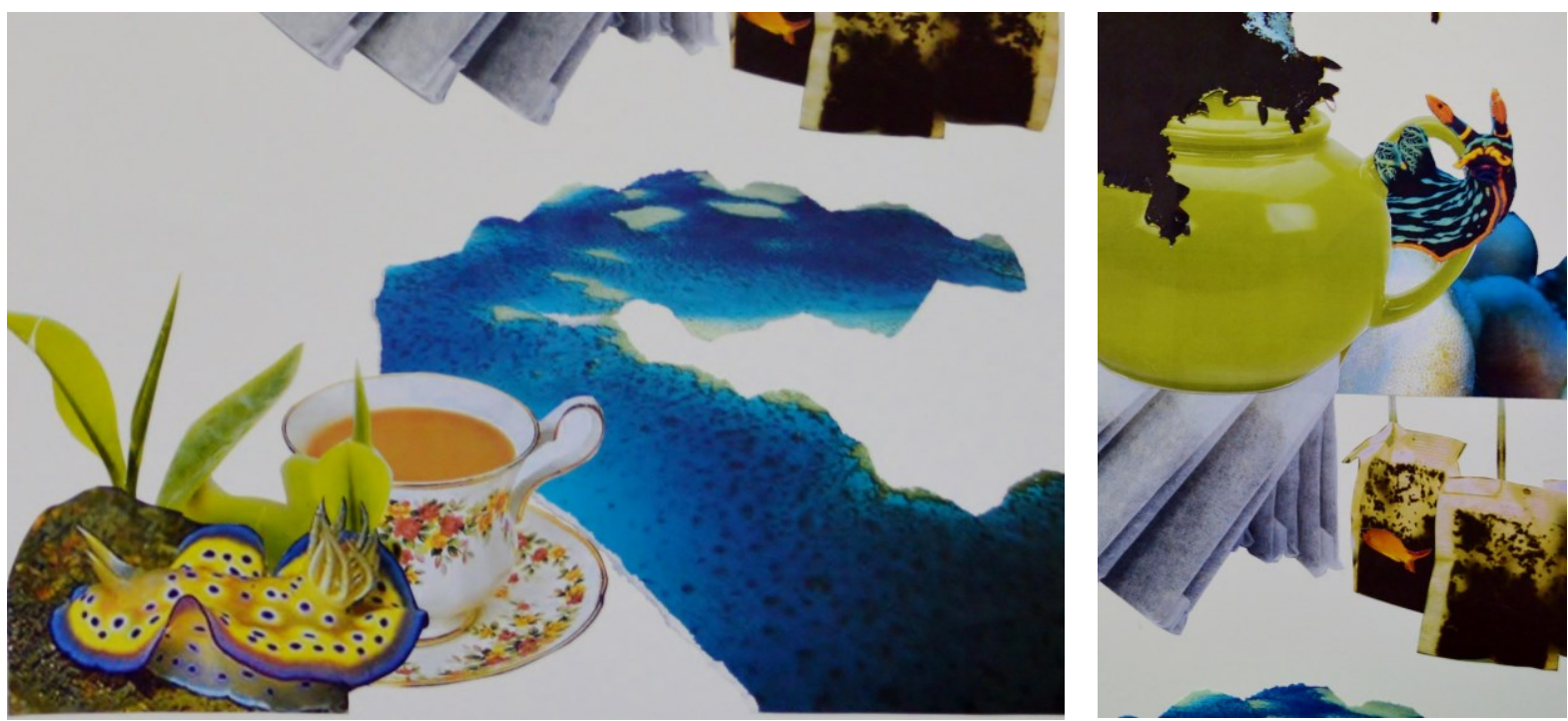

Figure 6: Jessica Mattner, Our Favourite Things (details), 2015, collage on paper. Used with permission. Photos by David Rousell.

An assemblage that smudges the boundaries between modes of existence, not just between species or types of things in a world, but more fundamentally, between natural and cultural phenomena as coextensive realities, between the colour green and our perception of green.

It's not a linear causal effect where what you do in the collaboration then directly leads to the next thing, it might just be a difference, an opening, a disruption that happens and allows something else to come in that's not predetermined.
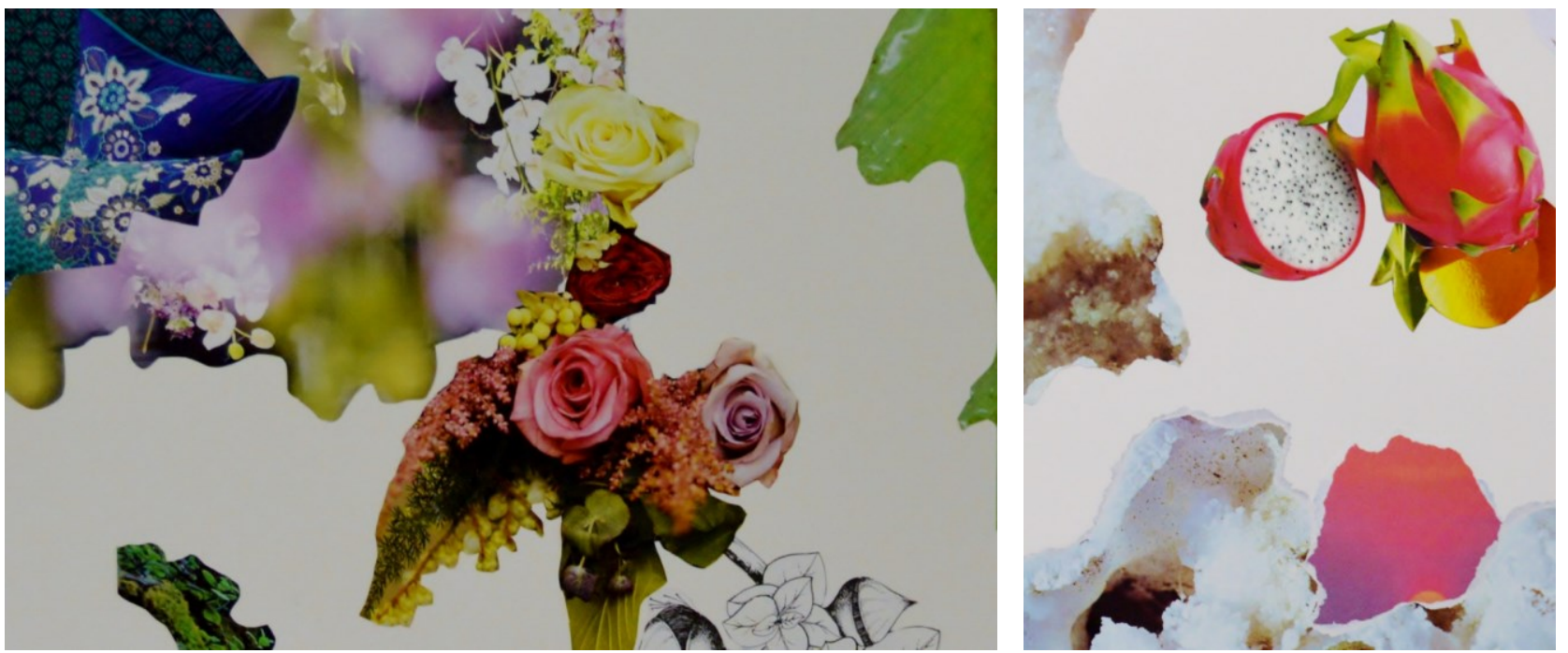

Figure 7: Jessica Mattner, Our Favourite Things (details), 2015, collage on paper. Used with permission. Photos by David Rousell.

Becomings-animal are basically of another power, since their reality resides not in an animal one imitates or to which one corresponds but in themselves, in that which suddenly sweeps us up and makes us become. (Deleuze and Guattari 1987: 279) 
Nan has macular degeneration so she'll just put like a random blob in the centre of something... and she says that's just what it's like for her to see an image and there's just like this distorted grey blur... that was really cool because that brought out like that her side of her.

The her side of her...

[...]a proximity, an indiscernibility that extracts a shared element from the animal far more effectively than any domestication, utilisation, or imitation could. (Deleuze and Guattari 1987: 279)

\section{Becoming-Woman}

Although all becomings are molecular, including becoming-woman, it must be said that all becomings begin with and pass through becoming-woman. It is the key to all the other becomings. (Deleuze \& Guattari 1987: 277)

Some of the work I really like is about a space within a space. And I thought it would be cool to make a space where I'm climbing all over the interior, so you realise that you're stepping into a work. I can show you the video (plays a video of herself crawling, rolling and wriggling across a black space). So, it will project up and around the outside of the calico, with the drawings crawling up and around the surface.
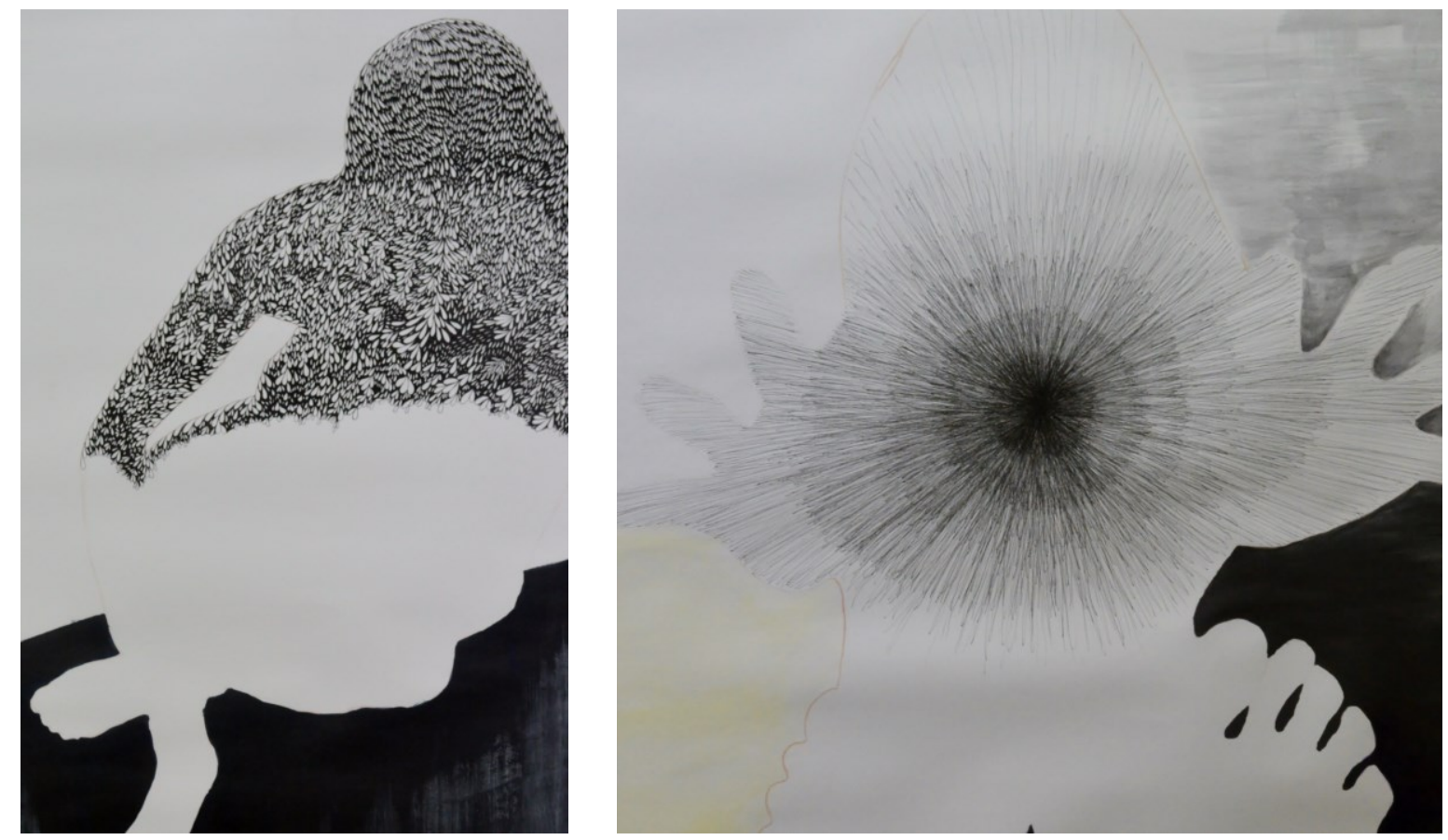

Figure 8: Emma Gardner, I don't quite get this "finding yourself" (where the fuck are you supposed to start?), 2015, mixed media. Used with permission. Photographs by David Rousell.

There's an animal quality to this. Did you think about that? 
No (laughs).

So, when you say it's about you experiencing the environment what does that mean?

I don't know. My reaction to experience as drawing. The drawing is like a transcript of my encoding of what was happening...

And there's something in this about the body in space...

My collaborative project was the figure that had made the marks in the sand...

Gestures that would then leave a trace on the environment... And there's the notion of the haptic as body space without cognition.

Gouges and scrapings, trace elements, to capture and edit the habitual patterns of the body a collaboration in movement
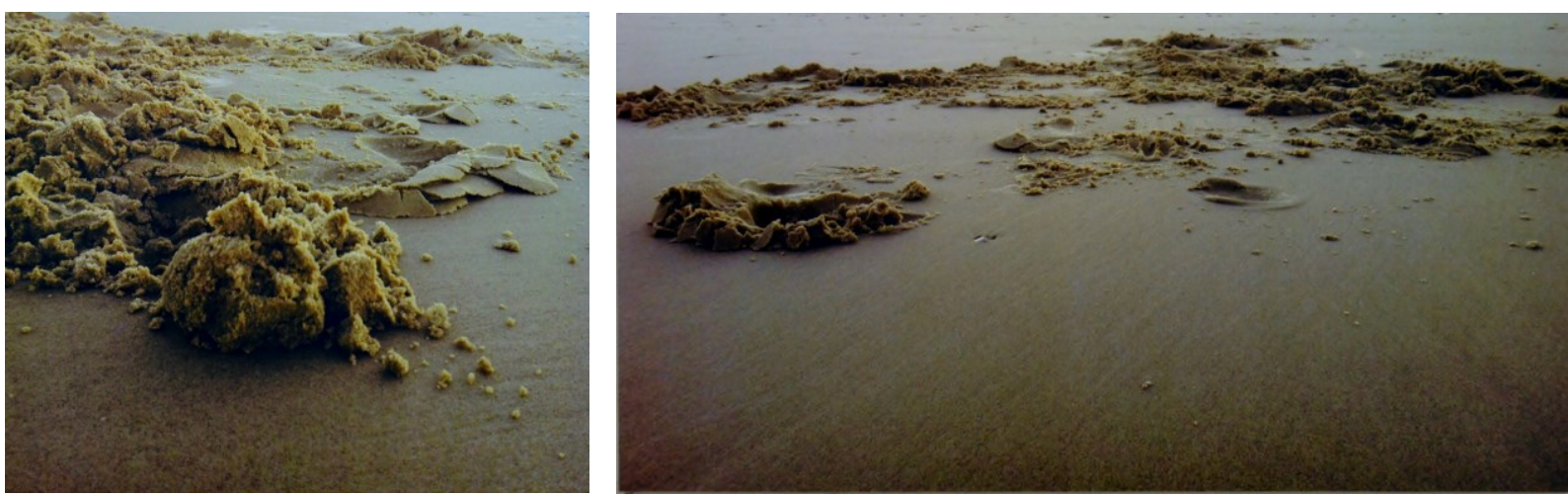

Figure 9: Emma Gardner, It's my perception (details), 2015. Performance and photography. Used with permission. Photographs by David Rousell.

The site lands itself for the body as much as the body lands the site. (Manning and Massumi 2014: 24)

These movements... they're somatic, but there's still a language to it. How it's made to feel... not so serious...

I wanted this to have a light element, but not just ridiculous. I wanted to have just bodies crawling all over there and engaging and not to have a dense critique on society at the moment, or where women stand in politics...

So, in a way it's postcritical... because it could have easily gone into that territory because the body is so huge in feminist discourse...

And I keep getting asked about feminism and this dialogue. I'm just doing the feminine body because I'm female. Being a female it has those stereotypes, but you don't have to bring it up in your dialogue of making so much anymore because it's a given, it's already been said. 
If that ecology tunes to categories such as colour or gender, these aspects of the field will continue to be foregrounded. The issue is not to deny this but to ask how these ecologies come to co-constitute a body in this or that way... a body is the how of its emergence, not the what of its form. (Manning 2013: 17, emphasis in original).

You don't have to express yourself as a feminist just because you're a female, and just because you work with the female body, I don't think that makes you a feminist either... it doesn't mean that you've got an agenda and you're trying to prove a point... it's just that you're exploring what you have so it's a tool that you can use...

What about the human?

The human... yeah, so it's the human space... because I'm not a man so I wouldn't use a man.

So, do you see it as a purely human body? That was my question before about the animal quality to the work.

I see it as a human body because I see it as me.

\title{
IV. Becoming-Molecular
}

Yes, all becomings are molecular: the animal, flower, or stone one becomes are molecular collectivities, haecceities, not molar subjects, objects or forms that we know from the outside and recognise from experience, through science, or by habit. (Deleuze and Guattari 1987: 275)

\author{
this collaboration between Brother and Sister \\ the relationships between and of us \\ the delicate nature of cell structures \\ making them large then compressing them down... \\ the micro and macro of us \\ even though the structure and form is the same \\ the differings change the form's effect
}

I started looking at cross sections of plant cell structures. I loved how it was symmetrical but not quite symmetrical, it was just so hard to replicate. I've never really had much of a basis in clay, I used found objects like leaves, bark, glue and stuff that I can physically ... even though clay is, but it's something that changes in the kiln process, it's delicate and then it's permanent, it's in that position. So, there'll be small prints magnified large, and my sculptures will be on the table and it will have a concave lens to make the large forms small. So even though we've got the same biology, we have these completely different personalities. 

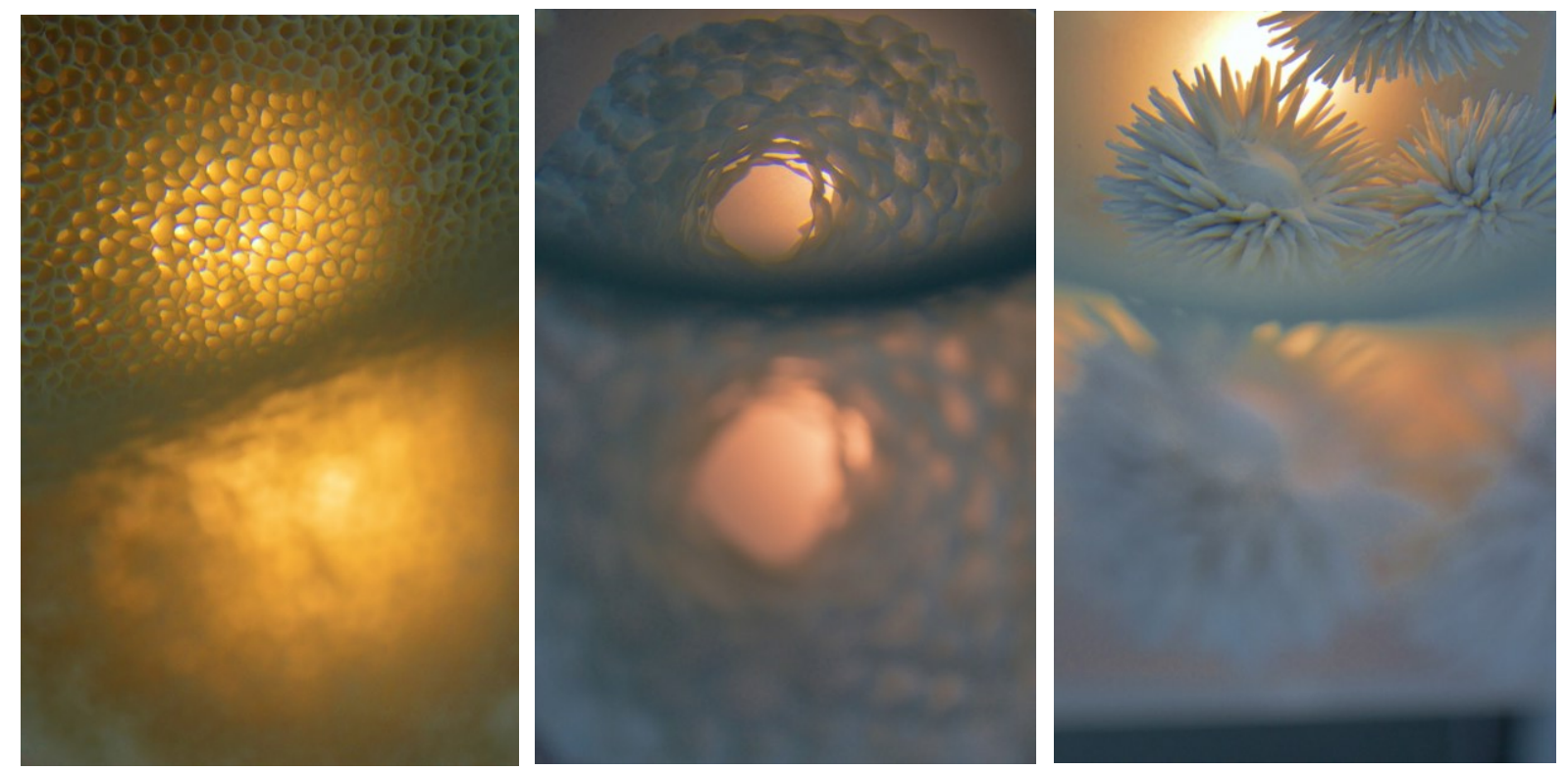

Figure 10: Michelle Butler, Cellularum (details), 2015. Mixed media. Used with permission. Photographs by David Rousell.

So, the material is a way of exploring your relationship as well.

Yeah, that's the process that we've both been going through. My brother's going to reconfigure the photographs of the form that I make and create his own prints. Originally what I thought we could do was print onto the lens and then it would project onto the wall.

I like that idea of live optics.

It's really intriguing about science and art. People think that art is really frivolous, but it's an expression of society as a whole. It's like a subconscious world that we know is happening, but they don't. It's kind of cheeky that we're in on this world, and they don't really know what we're doing. Which actually is kind of like a science experiment in itself!
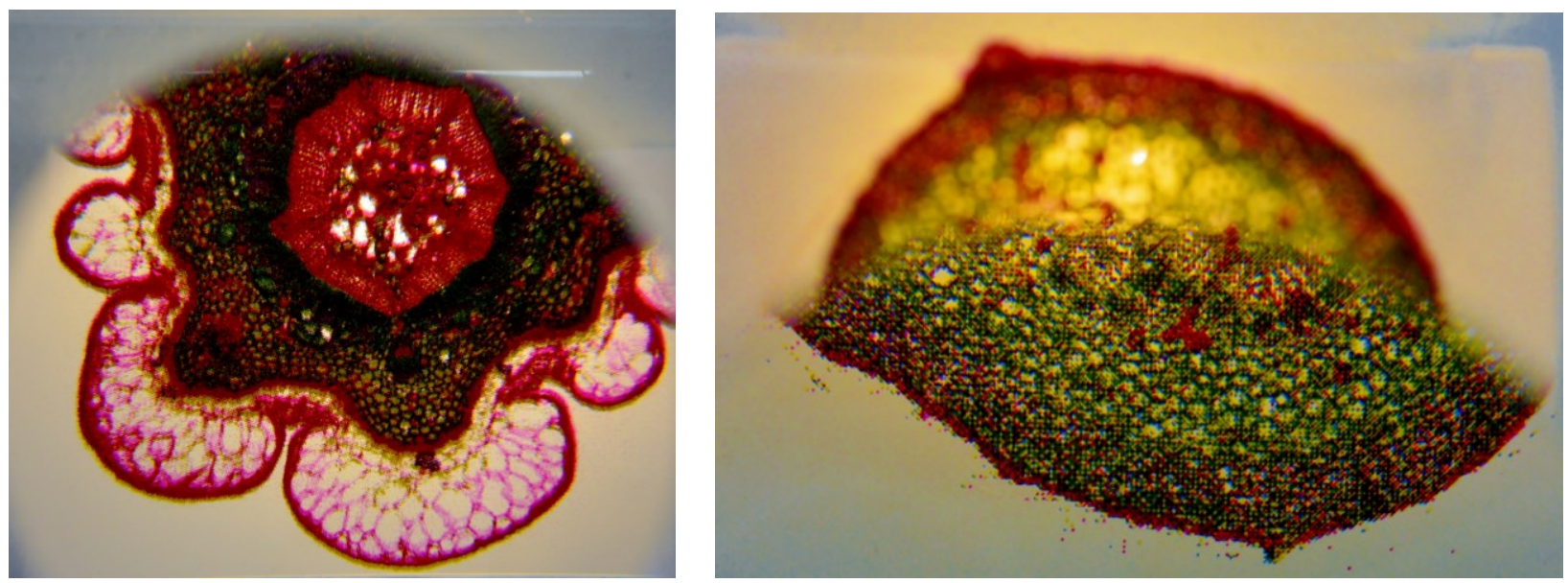

Figure 11: Michelle Butler, Cellularum (details), 2015. Mixed media. Used with permission. Photographs by David Rousell.

When you have the techniques of manipulating consciousness (laughs). It made me think too with the optical lens, about different philosophical perspectives and ontologies that affect our experience 
of the world... So how would you describe the process of collaborating not just with another person, but with these different lenses, and materials, and qualities of objects?

With my brother, we have a pretty easy relationship... because we both have the same level of making with printmaking... we've both grown up close to each other... we've got the same kind of mentality... but different too because we've had different experiences with socialising. We're worldly in different respects. It's nice working with another person because you're both responsible. You both have the same love for it.

What I find from collaboration is how attuned I become from someone else's idea and their response to mine. That flash where someone writes something or draws or says something and you have this immediate response. It's interesting because by introducing another person into this assemblage of artmaking, it then seems to change the relationship with the materials too.

Like a palimpsest. All these different layers of different works on top of each other and they have a relationship between all of those.

Those are the maps, the cartographies. Things are hidden yet still registering on the surface.

And with the development of the optical apparatus, that was a huge influence. It leads me into the world of the minute... It allowed me to put the flip on making something big and then shrinking it down, playing with what your brain knows is too small to see but making it kind of... there... it's a really bizarre feeling.

\section{Conclusion: Inventing New Forms of Life}

In this article, we have proposed the concept and practice of collaboration as a technique that orientates visual arts education towards 'becoming a work of art', rather than 'becoming an artist'. Each of the diagrams above has contributed to a distinct sense of the work of art as a distributed process of becoming that is irreducible to any essentialised identity, self or representation. In doing so, we have attempted to rehabilitate the practices and processes of visual arts education from 'under the crushing weight of several millennia of humanist thought' (Snaza and Weaver 2015: 1). Much of this weight can be attributed to dualistic, Western ontologies that insist on an essential and exceptional Being at the core of the individual human, for which art serves as the conduit of intentionality (Shaviro 2009). As Manning (2013: 46) argues:

there are few starting points as lethal as the totalitarianism of Being. "I" is a habit, and where it leads is toward the supremacy of the human. Being and the human-assupreme cannot be disengaged, and with the human at the centre, the frame is unequivocally in place for the eclipsing of the complexity of other ecologies, of other surfaces of experience.

If we are to resist the weight of humanism and consequential eclipsing of more than human ecologies of experience, then we believe that arts education needs to pivot on the processual event of making and being made. We therefore recognise that becoming a work of art is a process that always exceeds itself; the process is more than what it leaves behind. 'Processually speaking, a making is always bigger than the made. The making includes, in germ, the form of what will come to be, as well as the functions its being, once arisen, will afford' (Massumi 2013: xi). It is not the 
individual artist who becomes, but the collective event of the work of art that individuates itself through becoming.

In this way, the concept of 'becoming a work of art' alters the trajectory of visual arts education towards an ecological aesthetics that is distributive, collective and processual in nature. For jagodzinski (2015: 131), arts education needs to entertain the end of human dominance and superiority in affirmative and experimental ways, such that 'the affects of pedagogy can penetrate at the unconscious level where the nerves are most vulnerable'. Collaboration then has the capacity to generate techniques of becoming that are conditional to the virtual, and propositional to a rapidly changing materiality outside of thought. In this vein, Courchesne (2009: 142) calls for visual arts education to produce 'beautiful evidence' which can 'trigger collective behaviours that will be required in the future to transform our systems from destructive to sustainable'. This foregrounds the capacity for arts education to translate seemingly irreconcilable conflicts, paradoxes and contradictions into patterns of contrast, evoking an ethico-aesthetics founded on 'a caring for the relating of things as such - a politics of belonging instead of a politics of identity... a pragmatic politics of the in-between' (Massumi 2015: 18).

How then might we translate these insights into speculative propositions for curricular and pedagogical innovations in arts education? While some scholars have argued that posthumanism signals 'the end of curriculum' (Gaztambide-Fernández 2015: 248), we have pursued a different trajectory in allowing collaborative experiments to generate new curricular techniques, grammars and ontological tools-what Colebrook (1999) has called 'strategies of becoming'. The applications of such strategies stretch beyond the restrictions and limitations of a curricular corset of fixed inputs and outcomes, as organised in linear time and space according to a humanist sense of control, progress and result. Rather, our strategies of becoming have foregrounded the reciprocal, interactive yet haphazard nature of art as a creative, life-giving process that includes the human as one element amongst a multitude of others.
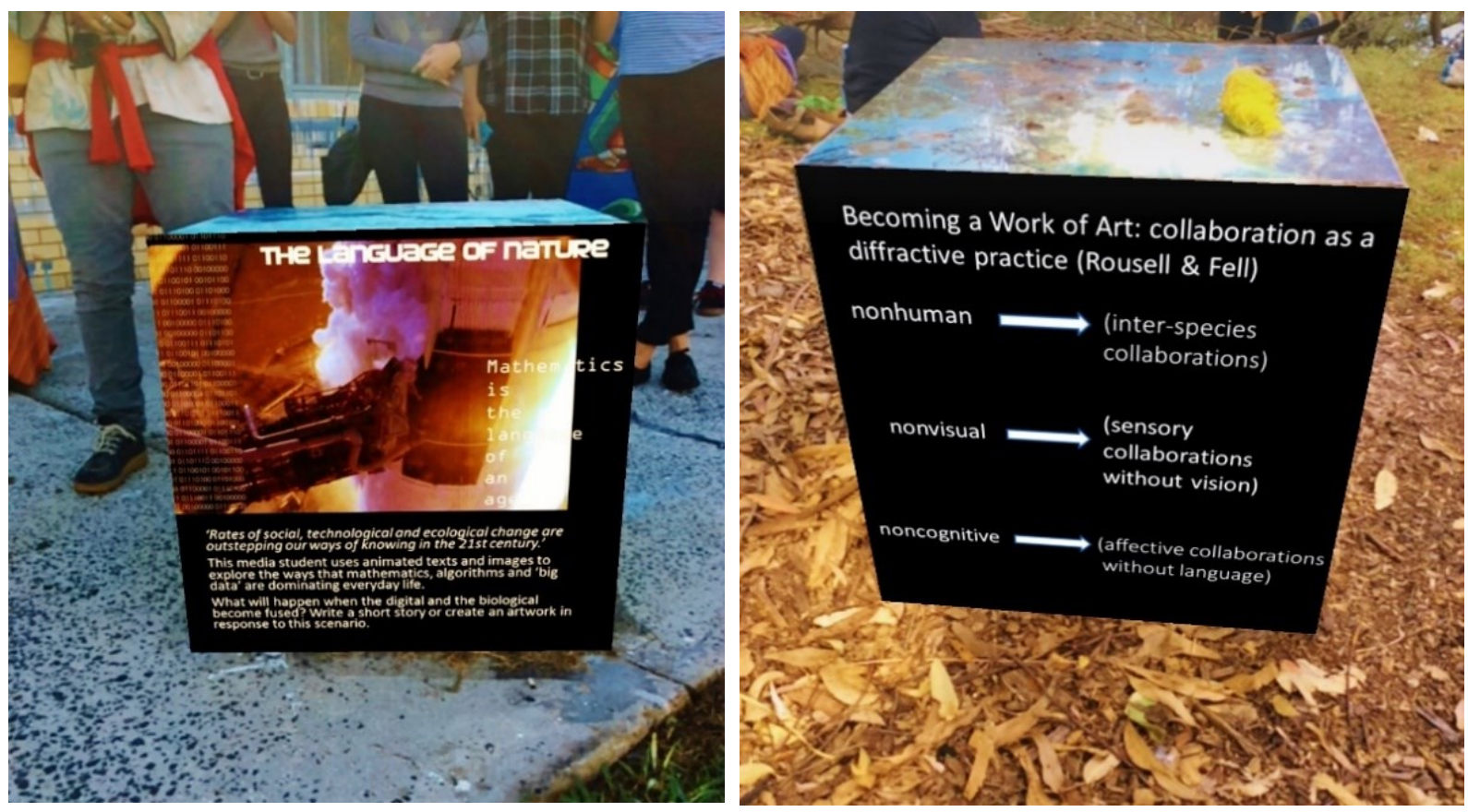

Figure 12: Examples of curricular imagery and text generated through the collaborations data event, and programmed for subsequent students to trigger using augmented reality applications. 
The images above show examples of how we have utilised insights and imagery from the collaboration data event to generate a series of curricular walks for students in subsequent years. Using augmented reality technologies to trigger various layers of content and instructions off the surfaces of the cubes, visual arts students are now able to engage with a curricular architecture that is mobile, contextual and widely distributed across the learning environments of the university campus. In curricular terms, such a strategic agenda has enabled us to design propositions, set ups and enabling constraints that actively foster queer collaborations, experimentations and belongings amongst different species, environments, practices, techniques and technologies. Interestingly, we found that these strategies have repositioned our role as educators, such that we have become relational elements or gears in a more widely distributed pedagogical machine. As the visual arts curriculum begins to take shape as a more than human form of life, we realise that our thinking and teaching have also been 'taken, captured, by a becoming that separates [us] from [our] own intentionality' (Stengers 2011: 519).

\section{References}

Barad, Karen (2007), Meeting the Universe Halfway: Quantum Physics and the Entanglement of Matter and Meaning, Durham, NC: Duke University Press.

Bolt, Barbara (2013), 'Toward a "New Materialism" through the arts', in E. Barrett and B. Bolt (eds.), Carnal Knowledge: Towards a 'New Materialism' through the Arts, London: I.B. Tauris, pp. 114.

Bennett, Jane (2010), Vibrant Matter: A Political Ecology of Things, Durham, NC: Duke University Press.

Braidotti, Rosi (2013), The Posthuman, Cambridge, UK: Polity Press.

Colebrook, Claire (1999), 'A grammar of becoming: Strategy, subjectivism, and style', in E. Grosz (ed.), Becomings: Explorations in Time, Memory, and Futures, Ithaca, NY: Cornell University Press, pp. 117-141.

Coole, Dianne, \& Frost, Samantha (2010), 'Introducing the New Materialisms', in D. Coole \& S. Frost (eds.), New Materialisms: Ontology, Agency and Politics, London: Duke University Press, pp. 1-43.

Courchesne, Luc (2009), 'Art, design and beyond', in B. Buckley and J. Conomos (eds.), Rethinking the Contemporary Art School: The Artist, the PhD and the Academy, Halifax: The Press of the Nova Scotia College of Art and Design, pp. 136-144.

Cutcher, Alexandra, Rousell, David and Cutter-Mackenzie, Amy, (2015), 'Findings, Windings and Entwinings: Cartographies of collaborative walking and encounter', The International Journal of Education Through Art, 11:3, pp. 449-458.

Deleuze, Gilles and Guattari, Felix (1987), A Thousand Plateaus: Capitalism and Schizophrenia, Minneapolis: University of Minnesota Press.

Deleuze, Gilles and Guattari, Felix (1994), What is Philosophy?, New York: Columbia University Press.

Deleuze, Gilles (1995), Negotiations: 1972-1990, New York: Columbia University Press.

Dolphijn, Rick and van der Tuin, Iris (2012), New Materialism: Interviews \& Cartographies (New Metaphysics), Ann Arbor, MI: Open Humanities Press. 
Ewing, Lauren (2009), 'Remixing the hive', in B. Buckley and J. Conomos (eds.), Rethinking the Contemporary Art School: The Artist, the PhD and the Academy, Halifax: The Press of the Nova Scotia College of Art and Design, pp. 159-163.

Foster, Hal, (1996), The Return of the Real, Cambridge: MIT Press.

Garoian, Charles R. (2014), 'In the event that art and teaching encounter', Studies in Art Education: A Journal of Issues and Research, 56:1, pp. 384-396.

Gaztambide-Fernández, Rubén A. (2015), 'Thinking beyond the Human', Curriculum Inquiry, 45:3, pp. 245-248.

Ingold, Tim (2013), Making: Anthropology, Archaeology, Art and Architecture, Oxon, UK: Routledge.

jagodzinski, jan and Wallin, Jason (2013), Arts-Based Research: A Critique and a Proposal. Rotterdam: Sense Publications.

jagodzinski, jan (2015), 'Affirmations and limitations of Ranciere's aesthetics: Questions for art and its education in the Anthropocene', in N. Snaza and J. Weaver (eds.), Posthumanism and Educational Research, New York: Routledge, pp. 121-133.

Lather, Patti and St. Pierre, Elizabeth Adams (2013), 'Post-qualitative research', International Journal of Qualitative Studies in Education, 26:6, pp. 629-633.

MacLure, Maggie (2013), 'Researching without representation: Language and materiality in post qualitative methodology', International Journal of Qualitative Studies in Education, 26:6, pp. 658-667.

Manning, Erin (2013), Always More Than One: Individuation's Dance, Durham, NC: Duke University Press.

Manning, Erin and Massumi, Brian (2014), Thought in the Act: Passages in the Ecology of Experience, Minneapolis: University of Minnesota Press.

Morton, Timothy (2016), Dark Ecology: For a Logic of Future Coexistence, New York: Columbia University Press.

Rousell, David \& Cutcher, Alexandra (2014), 'Echoes of a c/a/r/tography: Mapping the practicum experience of pre-service visual arts teachers in the "Visual Echoes Project", , Australian Art Education, 36:2, pp. 63-76.

Rousell, David (2015), 'The cartographic network: Re-imagining university learning environments through the methodology of immersive cartography', Multidisciplinary Research in the Arts. 5:1, pp. 1-33.

Rousell, David (2016), 'Dwelling in the Anthropocene: Reimagining university learning environments in response to social and ecological change', Australian Journal of Environmental Education, 32:2, pp. 137-153.

Rousell, David (2017). 'Mapping the data event: A posthumanist approach to art|education/research in a regional university, in L. Knight \& A. L. Cutcher (eds.), Arts, research, education: Connections and directions, New York: Springer International Publishing.

Salazar, Stacey (2013), 'Studio interior: Investigating undergraduate studio art teaching and learning', Studies in Art Education: A Journal of Issues and Research, 55:1, pp. 64-78. 
Shaviro, Steven (2009), Without Criteria: Kant, Whitehead, Deleuze, and Aesthetics, Cambridge: MIT Press.

Sholette, Gregory (1999), Counting on your collective silence: Notes on activist art as collaborative practice, Afterimage: The Journal of Media and Cultural Criticism, pp. 18-20.

Snaza, Nathan and Weaver, John (2015), 'Introduction: Education and the posthumanist turn', in N. Snaza and J. Weaver (eds.), Posthumanism and Educational Research, New York: Routledge, pp. 1-16.

Rotas, Nikki and Springgay, Stephanie (2015), 'How do you make a classroom operate like a work of Art? Deleuzeguattarian methodologies of research-creation', International Journal of Qualitative Studies in Education, 28:5, pp. 552-272.

Stengers, Isabelle (2005), 'Introductory notes on an ecology of practices', Cultural Studies Review, 11:1, pp. 183-196.

Stengers, Isabelle (2011), Thinking with Whitehead: A Free and Wild Creation of Concepts, Cambridge: Harvard University Press.

St. Pierre, Elizabeth (2013), 'The posts continue: Becoming', International Journal of Qualitative Studies in Education, 26:6, pp. 646-657.

Whitehead, Alfred North (1978), Process and Reality, New York: The Free Press.

Zepke, Stephen (2005), The Abstract Machine: Art and Ontology in Deleuze and Guattari, New York, NY: Routledge. 